\title{
Occurrences of whale shark (Rhincodon typus Smith, 1828) in the Saint Peter and Saint Paul archipelago, Brazil
}

\author{
Hazin, FHV., Vaske Júnior, T., Oliveira, PG., Macena, BCL.* and Carvalho, F. \\ Laboratório de Oceanografia Pesqueira, Departamento de Pesca e Aqüicultura - DEPAq, \\ Universidade Federal Rural de Pernambuco - UFRPE, \\ Av. Dom Manuel de Medeiros, s/n, Dois irmãos, CEP 52171-900, Recife, PE, Brazil \\ *e-mail: brunomacena@ hotmail.com
}

Received June 8, 2006 - Accepted August 17, 2006 - Distributed May 31, 2008

(With 3 figures)

\begin{abstract}
The Saint Peter and Saint Paul Archipelago in the central tropical Atlantic, is an important ground of whale sharks that are commonly sighted throughout the year close to the fishing boats in the adjacencies of the islands. In sightings reported between February 2000 and November 2005, the lengths of the individuals ranged between 1.8 to $14.0 \mathrm{~m}$. The causes of these concentrations in the archipelago are still unclear, once there are no upwellings and plankton concentrations for feeding, and no reproductive activities were reported. Nevertheless, they could be associated to the spawning period of the abundant flying fishes, mainly in the first semester, when sightings were more frequent.
\end{abstract}

Keywords: whale shark, Saint Peter and Saint Paul archipelago.

\section{Ocorrências de tubarão-baleia (Rhincodon typus Smith, 1828) no arquipélago de São Pedro e São Paulo, Brasil}

\begin{abstract}
Resumo
O Arquipélago de São Pedro e São Paulo situado na área central tropical do Atlântico, é um importante local de concentração de tubarões-baleia, que são vistos ao longo de todo ano, próximos às embarcações de pesca nas adjacências das ilhas. Em avistagens registradas entre fevereiro de 2000 e novembro de 2005, os comprimentos dos indivíduos variaram entre 1,8 e 14 m. As causas destas concentrações no arquipélago ainda não são claras, uma vez que não há há ressurgências e grandes concentrações de plâncton no arquipélago, e também não foram observadas atividades reprodutivas. No entanto, podem estar associadas ao período de desova dos peixes-voadores, marcadamente no primeiro semestre, quando as aparições são mais freqüentes.
\end{abstract}

Palavras-chave: tubarão-baleia, arquipélago de São Pedro e São Paulo.

\section{Introduction}

The whale shark, Rhincondon typus is the biggest fish of the world, inhabiting all tropical and subtropical oceans, with records of them in warm tropical waters, except in the Mediterranean (Compagno, 1984; Colman, 1997). Although whale sharks have a wide distribution, knowledge of its biology and ecology still limited (Jones and Kaly, 1995). In general, occurrences of whale sharks are sporadic and unexpected, which can be associated with the limited knowledge of its ecology (Colman, 1997).

According to Gudger $(1922,1923)$ cited by Soto (2001), the first record of a whale shark in Brazilian waters was on the coast of Bahia. Since then about 63 records of whale shark are known in Brazilian waters (Bertoncini and Sampaio, 2002), ranging from 1.8 to $14 \mathrm{~m}$ (Edwards and Lubbock, 1982; Gaelzer, 1985; Gadig, 1991; 1994;
1997; 2005; Soto, 1995; Alecrim-Santos et al., 1988; Amorim and Ferreira, 2002, Campos et al., 2005).

Due to the strategic position of the Saint Peter and Saint Paul Archipelago (SPSPA) between the two hemispheres, and the Atlantic and African continents, the archipelago is an important concentration ground of migratory species such as tunas, billfishes, turtles, dolphins, and the whale sharks. It is one of the smallest, most isolated groups of oceanic islands in the world. The rocky islands are particularly interesting from the population biology and biogeographical perspectives because of their very small size and isolation. They are uniquely influenced by both the superficial Southern Equatorial Current flowing eastward, and the Equatorial Undercurrent flowing westward. The area has been visited by scientific expeditions 
since 1799 when the inhospitable nature and inaccessibility of the archipelago prevented detailed biological studies. However, since the establishment of a scientific research station by the Brazilian Navy, in July 1998, researchers have been able to visit the island periodically and continually.

Records of whale shark in the SPSPA were reported by Edwards and Lubbock (1982), Gadig (1994), and Rangel (1998). Since the beginning of scientific research in the SPSPA in 1998, whale sharks have been frequently sighted around the islands.

The aim of this study is to compile the existing data of sightings of the whale sharks recorded in the SPSPA, localize the sighting points, estimate the lengths of individuals, and observe the sighting frequency throughout the year.

\section{Material and Methods}

The Saint Peter and Saint Paul Archipelago is a very small group of rocky islands located on the midAtlantic Ridge, just north of the Equator $\left(00^{\circ} 55^{\prime} \mathrm{N}\right.$ and $\left.29^{\circ} 21^{\prime} \mathrm{W}\right), 1,000 \mathrm{~km}$ from the Brazilian coast, and 1,890 $\mathrm{km}$ from Senegal, Africa (Figure 1). Data were obtained between February 2000 and November 2005, from recorded registers, besides interviews and information provided by fishermen and researchers that utilized the scientific station. Total length was obtained by visual estimate, or using a tape measure when appropriate. A $\chi^{2}$ text was used to compare sightings with moon phase.

\section{Results}

In the present study, 54 observations of whale shark were made in the SPSPA (Table 1). Total length ranged from 1.8 to $14 \mathrm{~m}$, although precise lengths were collected only on one occasion with a metric cable, in June 2001 (Figure 2). The maximum length of $14 \mathrm{~m}$ on March

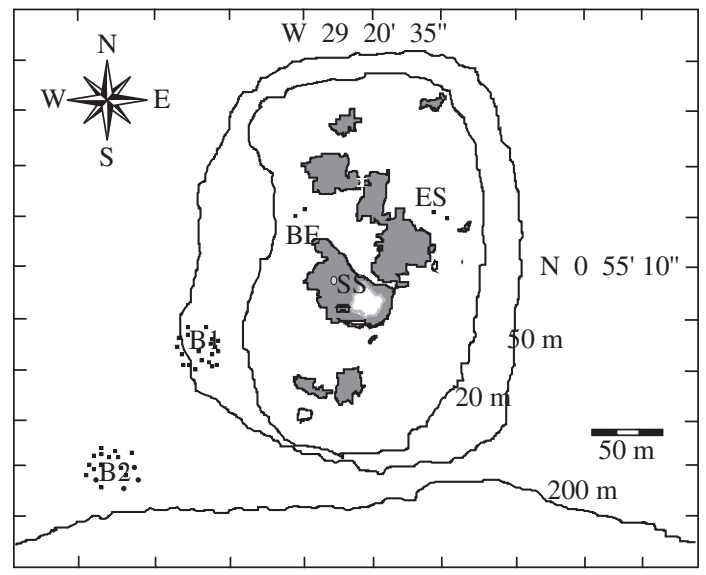

Figure 1. Saint Peter and Saint Paul Archipelago in the central Atlantic with isobaths. B1 - buoy 1 (23); B2 - buoy 2 (18); BE - bay entrance (2); ES - east side (2); SS - scientific station. $27^{\text {th }} 2000$ was estimated comparing the fish to the length of the fishing boat since the whale shark remained for 10 minutes by the side of the boat. Most sightings were made in the morning (25), and in the afternoon (16). In January 2004, four sharks were seen at night, one of them remained for 360 minutes beside the boat. Sighting times ranged between 1 to 360 minutes, with no correlation between the moon phase $\left(\chi^{2} ; \mathrm{p}<0.001\right)$. Sex determination of all individuals was not possible due to most of the sightings being made from the fishing boats and not from underwater observations. In the SPSPA, the whale shark did not present a clear period of occurrence, but the sightings were more common mainly during the first semester (Figure 3).

Twenty three sightings were reported at buoy 1 , eighteen at buoy 2 where fishing boats are commonly moored and ten were not described (Figure 4). Only two sightings were recorded on the east side, and on one occasion very close to the rocks. Probably the sightings of June $18^{\text {th }}, 19^{\text {th }}$ and $20^{\text {th }}, 2000$, were of the same individual of $8 \mathrm{~m}$ TL. The same situation may have occurred with the sighting recorded on March $27^{\text {th }}$ and $28^{\text {th }}, 2002$, both for individuals of $5 \mathrm{~m} \mathrm{TL}$. Two whale sharks presented some remarkable characteristics, one shark (5 m TL) had the top of the caudal fin cutted, and another shark $(8 \mathrm{~m}$ TL) did not present the first dorsal fin. Both were photographed.

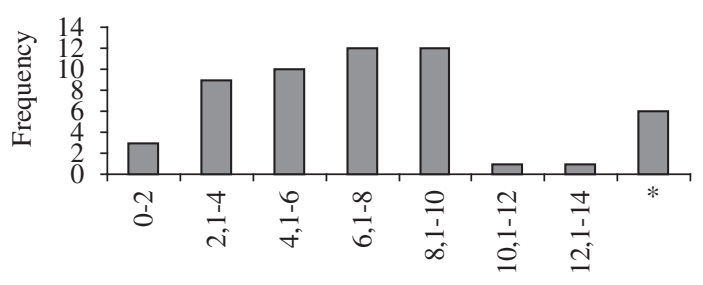

Estimated length (m)

Figure 2. Length distribution of whale sharks sighted in the Saint Peter and Saint Paul Archipelago between February 2000 and November 2005. *Undefined.

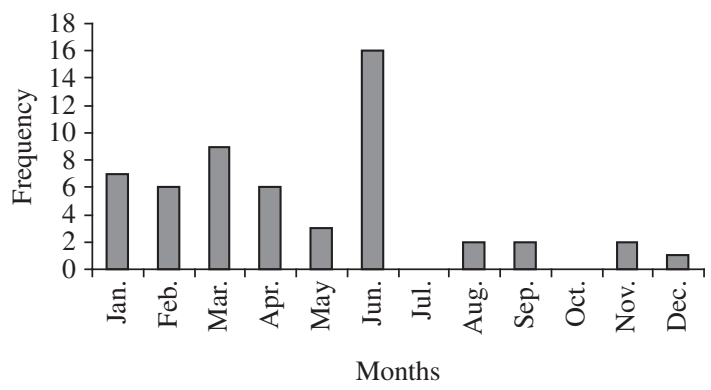

Figure 3. Monthly frequencies of sightings of whale shark in the Saint Peter and Saint Paul Archipelago. 
Table 1. Whale shark occurrences in Saint Peter and Saint Paul Archipelago.

\begin{tabular}{|c|c|c|c|c|c|c|}
\hline $\mathbf{N}$ & Date & $\begin{array}{c}\text { Est. Lenght } \\
\text { (m) }\end{array}$ & Sex & Day hour & $\begin{array}{c}\text { Sight. time } \\
\text { (minutes) }\end{array}$ & Moon \\
\hline 1 & fev/2000 & 9 & - & morning & 10 & - \\
\hline 2 & $11 / 03 / 2000$ & 6 & - & - & - & first quarter \\
\hline 3 & $19 / 03 / 2000$ & 10 & - & 8:00 AM & 45 & full \\
\hline 4 & $27 / 03 / 2000$ & 14 & - & 6:00 PM & 10 & last quarter \\
\hline 5 & aug/2000 & - & - & - & - & - \\
\hline 6 & $04 / 03 / 2001$ & 8 & - & afternoon & 15 & first quarter \\
\hline 7 & $24 / 03 / 2001$ & 5 & - & 1:00 PM & 15 & new \\
\hline 8 & april/2001 & 8 & - & - & - & - \\
\hline 9 & 18/04/2001 & - & - & 12:00 AM & - & last quarter \\
\hline 10 & $12 / 06 / 2001$ & 7,8 & $\mathrm{~F}$ & 10 to $11: 00 \mathrm{AM}$ & 60 & last quarter \\
\hline 11 & $12 / 06 / 2001$ & 12 & M & 10 to $11: 00 \mathrm{AM}$ & 60 & last quarter \\
\hline 12 & aug/2001 & - & - & - & - & - \\
\hline 13 & $20 / 09 / 2001$ & 3 & - & 7:00 AM & 20 & new \\
\hline 14 & mar/2002 & - & - & - & - & - \\
\hline 15 & 27/03/2002 & 5 & - & $12: 00 \mathrm{AM}$ & 15 & full \\
\hline 16 & $28 / 03 / 2002$ & 5 & - & 7:00 AM & 5 & full \\
\hline 17 & 01/06/2002 & 10 & - & morning & 2 & last quarter \\
\hline 18 & $02 / 06 / 2002$ & 10 & - & - & - & last quarter \\
\hline 19 & $02 / 06 / 2002$ & 3 & - & - & - & last quarter \\
\hline 20 & $18 / 06 / 2002$ & 8 & - & 3:00 PM & 30 & first quarter \\
\hline 21 & $19 / 06 / 2002$ & 8 & - & 6:00 AM & 15 & first quarter \\
\hline 22 & $20 / 06 / 2002$ & 8 & - & 1:00 PM & 15 & first quarter \\
\hline 23 & $23 / 12 / 2002$ & - & - & morning & - & full-first quater \\
\hline 24 & $25 / 01 / 2003$ & 6 & - & afternoon & 30 & last quarter \\
\hline 25 & $09 / 02 / 2003$ & 6 & - & morning & 40 & first quarter \\
\hline 26 & $13 / 02 / 2003$ & 10 & - & morning & 20 & full \\
\hline 27 & $23 / 02 / 2003$ & 2 & - & afternonn & 40 & last quarter \\
\hline 28 & $19 / 01 / 2004$ & 8 & - & 2:00 AM & 1 & new \\
\hline 29 & $21 / 01 / 2004$ & 4 & - & 8:42 PM & 1 & new \\
\hline 30 & $22 / 01 / 2004$ & 1,8 & - & 8:00 PM & 2 & new \\
\hline 31 & $24 / 01 / 2004$ & 10 & - & 10:35 PM & 8 & new \\
\hline 32 & $25 / 01 / 2004$ & 7 & - & 5:00 PM & 10 & new \\
\hline 33 & $29 / 01 / 2004$ & 7 & - & 11 to $5: 00 \mathrm{AM}$ & 360 & first quarter \\
\hline 34 & $31 / 03 / 2004$ & 8 & - & 5:00 PM & 0,40 & first quarter \\
\hline 35 & 04/04/2004 & 9 & - & 6:00 PM & 2 & full \\
\hline 36 & 02/06/2004 & 4 & - & 6:00 PM & 15 & full \\
\hline 37 & 03/06/2004 & 4 & - & $6: 00 \mathrm{AM}$ & 10 & full \\
\hline 38 & $04 / 06 / 2004$ & 4 & - & 5:00 PM & 15 & full \\
\hline 39 & $05 / 06 / 2004$ & 4 & - & 6:00 AM & 1 & full \\
\hline 40 & 06/06/2004 & 4 & - & $9: 30 \mathrm{AM}$ & 15 & full-first quarter \\
\hline 41 & $19 / 02 / 2005$ & 2 & - & 2:35 PM & - & first quarter \\
\hline 42 & $19 / 02 / 2005$ & 6 & - & $2: 35 \mathrm{PM}$ & 38 & first quarter \\
\hline 43 & $12 / 04 / 2005$ & 6 & - & $7: 43$ AM & - & first quarter \\
\hline 44 & $18 / 04 / 2005$ & 9 & - & 9:30 AM & - & first quarter \\
\hline 45 & $25 / 04 / 2005$ & 7 & - & 11:10 AM & 20 & full \\
\hline 46 & 06/05/2005 & 7 & - & $11: 20 \mathrm{AM}$ & 40 & new \\
\hline 47 & $11 / 05 / 2005$ & 10 & - & 11:00 AM & 60 & new \\
\hline
\end{tabular}


Table 1. Continued...

\begin{tabular}{ccccccl}
\hline $\mathbf{N}$ & Date & $\begin{array}{c}\text { Est. Lenght } \\
(\mathbf{m})\end{array}$ & Sex & Day hour & $\begin{array}{c}\text { Sight. time } \\
\text { (minutes) }\end{array}$ & Moon \\
\hline 48 & $11 / 05 / 2005$ & - & - & $11: 00 \mathrm{AM}$ & - & new \\
49 & $03 / 06 / 2005$ & 10 & - & $11: 30 \mathrm{AM}$ & - & new \\
50 & $06 / 06 / 2005$ & 3 & - & $10: 20 \mathrm{AM}$ & - & new \\
51 & $06 / 06 / 2005$ & 10 & - & $10: 20 \mathrm{AM}$ & - & new \\
52 & $21 / 09 / 2005$ & 8 & - & $6: 30 \mathrm{AM}$ & 5 & full \\
53 & $25 / 11 / 2005$ & 5 & $\mathrm{M}$ & $11: 25 \mathrm{AM}$ & 1 & last quarter \\
54 & $27 / 11 / 2005$ & 5 & $\mathrm{M}$ & $5: 45 \mathrm{AM}$ & 4 & last quarter-new \\
\hline
\end{tabular}

\section{Discussion}

The movements of the whale sharks can be related to productivity and invertebrate egg deposition (Compagno, 1984; Colman, 1997), commonly associated with turbulence around oceanic islands, as in the SPSPA. Gunn et al. (1992) pointed out the association between whale sharks and tunas in the Coral Sea, where the sharks concentrate for predation upon the lantern fishes during the reproduction period of these fishes. In the case of SPSPA, shoals of yellow fin tuna (Thunnus albacares), concentrate around the islands from October onwards, to feed upon the flying fish (Cypselurus cyanopterus) that reproduce in the area mainly between December and March (Lessa et al., 1998; Lessa et al., 1999; Vaske-Jr, et al., 2003; Vaske Jr. et al., 2005). Although no filter feeding activity has been reported during sightings. Eggs and larvae of flying fish are the most abundant planktonic item in the adjacencies of the SPSPA that could be the main food item for whale sharks in this period.

The SPSPA does not present upwellings or high primary productivity in the adjacencies (Travassos et al., 1999) that could explain the concentrations of whale sharks as observed by Arnborn and Papastravrou (1988) in the Galapagos Islands. Thus, if the whale shark utilizes the SPSPA for feeding, it is probable that the more frequent sightings in the first semester could be associated with the greater abundance of eggs and larvae of the flying fish. No reproductive activities were reported or observed, so the whale shark could also utilize the archipelago as a resting point on their migratory routes in the Atlantic, which remain unknown.

The sighting time was variable, which means that sharks are not annoyed with the presence of the boats; on the contrary, they may even be attracted by the boats.

Future studies are necessary for knowledge on the whale shark in the SPSPA, including telemetry as used by Eckert and Stewart (2001) to elucidate the migratory routes, and observe if the individuals of the SPSPA come from another point in the oceans, or if they are part of a resident population.

Acknowledgements - The authors are grateful to the SECIRM (Interministerial Commission for Sea Resources), and to CNPq (National Council of Scientific and Technological Development) for the logistical support.

\section{References}

ALECRIM-SANTOS, CA., ANDREATTA, JV. and GOMES, UL., 1988. Sobre a ocorrência de Rhincodon typus (Smith, 1829) (Elasmobranchii, Rhincodontidae) em águas brasileiras e aspectos de sua taxonomia. Acta Biol. Leopoldensia, vol. 10, no. 2, p. $175-182$.

AMORIM, AF. and FERREIRA, LA., 2002. Occurrence of a small free living whale shark, Rhincondon typus (Smith, 1828) off subtropical waters of Western Atlantic. In Resumos da III Reunião da Sociedade Brasileira para o Estudo dos Elasmobrânquios - SBEEL, 2002, João Pessoa, PB, vol. 1. p. 37-38.

ARNBORN, T. and PAPASTRAVROU V., 1988. Fish in association with whale sharks Rhiniodon typus near the Galapagos islands. Noticias de Galapagos, no. 46, p. 13-15.

BERTONCINI, AA. and SAMPAIO, CLS., 2002. Novos Registros de Tubarão-Baleia, Rhincodon typus SMITH, 1829 no Litoral da Bahia, nordeste do Brasil. In: Resumos da III Reunião da SBEEL, 2002, João Pessoa, PB, vol. 1. p. 29-30.

CAMPOS, CEC., SILVA, MB., TARGINO, SG. and BORGOFF, C., 2005. First record of whale shark, Rhincodon typus (Condrichthyes: Rhincodontidae) in Atol das Rocas, Brazil. In Resumos do XVI Encontro Brasileiro de Ictiologia, janeiro de 2005, João Pessoa, PB. p. 203.

COMPAGNO, LJV. 1984. Sharks of the World. An Annotated and Illustrated Catalogue of Shark Species Known to Date. FAO Species Catalogue. vol. 4, Parts 1 and 2. FAO Fish. Synopsis 125, FAO, Rome.

COLMAN, JG., 1997. A review of the biology and ecology of the whale shark. J. Fish Biol. no. 51, p. 1219-1234.

ECKERT, SA. and STEWART, BS., 2001. Telemetry and satellite tracking of whale sharks, Rhincodon typus, in the Sea of Cortez, Mexico, and the North Pacific Ocean. Env. Biol. Fishes., vol. 60, no 1-3, p. 299-308.

EDWARDS, A. and LUBBOCK, R., 1982. The shark population of Saint Paul's Rocks. Copeia., no. 1, p. 223-225.

GADIG, OBF., 1991. Dados complementares sobre a ocorrência do tubarão-baleia, Rhincodon typus Smith, 1829 (Orectolobiformes, Rhincodontidae) no Brasil. In Resumos do Encontro Nacional de Pesca e Aqüicultura, Santos. p. 113.

GADIG, OBF., 1994. Fauna de tubarões da costa norte/nordeste do Brasil (Condrichthyes, Elasmobranchii). (Dissertação de mestrado) - Departamento de Sistemática e Ecologia da Universidade Federal da Paraíba. 230 p. 
GADIG, OBF., 1997. Avistagens de tubarão-baleia, Rhincodon typus, durante as operações de caça à baleia no litoral da Paraíba, nordeste do Brasil. In: Resumos do I Encontro da Sociedade Brasileira para Estudos de Elasmobrânquios. Universidade estadual de Santa Cruz, Ilhéus. p. 101.

GADIG, OBF., 2005. Occurrence, distribution, and conservation of the whale shark in the Western South Atlantic. Abstracts from the International Whale Shark Conference, Perth, Australia. p. 22.

GAELZER,LR., 1985. Ocorrência de tubarão-baleia (Rhincodon typus) (Smith, 1828) na costa brasileira. In Resumos do XII Congresso Brasileiro de Zoologia. Campinas. 378 p.

GUDGER, EW., 1922. The fourth record of occurrence in the Atlantic ocean of the whale-shark, Rhincodon typus. Scienc, no. 56 , p. 251-252.

-, 1923. An extraordinary capture of the giant shark, Rhincodon typus. Natural History, no. 23, p. 62-63.

GUNN, JS., WHITELAW, AW., DAVIS, TLO., BAILEY, K. and ITANO, DG., 1992. Tuna tagging in the Coral Sea. Australian Fisheries, no. 51, p. 22-24.

JONES, GP., KALY, UL., 1995. Conservation of rare, threatened and endemic marine species in Australia. In ZANN, LP. and KAILOLA, PK. (Eds). State of the marine environment report for Australia, Technical Annex 1: The marine environment. Ocean Rescue 2,000 Program, Department of the Environment, Sport and Territories.

LESSA, R., MAFALDA-JR., P.,ADVÍNCULA, R., LUCCHESI, R., BEZERRA-JR., JL., VASKE-JR., T. and HELLEBRANDT, D., 1999. Distribution and abundance of ichthyoneuston at seamounts and islands off north-eastern Brazil. Arch. Fish. Res., vol. 47, no. 2-3, p. 133-146.

MONTEIRO, A., VASKE-JR., T., LESSA, RP. and EL-DEIR, ACA., 1998. Exocoetidae (Beloniformes) off northeastern Brazil. Cybium, vol. 22, no. 4, p. 395-403.

RANGEL, CE., 1998. Novo registro de ocorrência de tubarãobaleia, Rhincodon typus (Orectolobiformes: Rhincodontidae), no Arquipélago de São Pedro e São Paulo. Bol. da SBEEL, no. 3 , p. 3 .

SOTO, JMR. and CASTRO-NETO, WN., 1995. Relação dos primeiros registros de tubarão-baleia, Rhincodon typus (Orectolobiformes: Rhincodontidae), em águas brasileiras, com a ampliação de sua distribuição para o sul do Brasil. In Resumos da VII Reunião do Grupo de Trabalho sobre Pesca e Pesquisa de Tubarões e Raias no Brasil. Rio Grande, RS. p. 67.

SOTO, JM., 2001. Annotated systematic checklist and bibliography of the coastal and oceanic fauna of Brazil. I Sharks. Mare Magnum, vol. 1, no. 1, p. 51-120.

TRAVASSOS, P., HAZIN, FHV., ZAGAGLIA, JR., ADVINCULA, R. and SHOEBER, J., 1999. Thermohaline structure around seamounts and islands off North-Eastern Brazil. Arch. Fish. Mar. Res., vol. 47, no. 2-3, p. 211-222.

VASKE-JR, T, VOOREN, CM. and LESSA, RP., 2003. Feedind strategy of yellowfin tuna (Thunnus albacares) and wahoo (Acanthocybium solandri) in the Saint Peter and Saint Paul Archipelago. B. Int. Pesca, vol. 29, no. 1, p. 173-181.

VASKE-JR., T., LESSA, RP., NÓBREGA, MF., MONTEALEGRE-QUIJANO, S., SANTANA, FM., and BEZERRA-JR., JL., 2005. A checklist of fishes from Saint Peter and Saint Paul Archipelago, Brazil. J. Applied Ichthyology, vol. 21, no. 1, p. 75-79. 